\title{
LEARNERS' ENCOUNTER WITH ARCHAEOLOGICAL FIELDWORK: A PUBLIC PARTICIPATION ARCHAEOLOGY ACCOUNT OF THE EAST FORT ARCHAEOLOGICAL PROJECT
}

\author{
DOI: http://dx.doi.org/10.17159/2223-0386/2017/n17a6
}

Anton $\mathrm{C}$ van Vollenhoven

North-West University (Mafikeng Campus)

antonv@archaetnos.co.za
Karin Scott \& Mariette Harcombe

Heritagewor $X$

fillthegap@heritageworx.co.za

\section{Abstract}

Public Archaeology as a concept is generally defined as civic involvement during the various public phases of Cultural Resources Management. The practice of archaeology in South Africa seldom extends towards public participation in archaeological activities or the production of knowledge. Public Archaeology constitute the active participation of the public in the archaeological excavation and the documentation of an archaeological site. The aim of the East Fort Archaeological Project is to provide an opportunity to members of the public interested in archaeology, as well as to assist high school learners and prospective tertiary students considering archaeology as a career, to participate in an active archaeological project regardless of their skills level. Initially the project was only aimed at high school learners, since heritage is included in the History curriculum for high school learners. Later members of the general public and primary school learners were included due to the interest shown in the project. This article provides an overview of the project from 2013 to the present. It looks at the different aspects thereof, consisting of an orientation course, educational excursion and practical archaeological field work. The project can be considered a success as it proves that the public can participate in and assist with the production of archaeological knowledge. It is foreseen that History teachers could be involved in similar projects that can be used to make history come alive for learners. It is also a first step in creating a heritage-literate society.

Keywords: Public Archaeology; History teaching; Heritage management; Education; Excavation; Documentation; Knowledge production.

\section{Introduction}

History, Archaeology and Heritage are three very closely related disciplines and may even be regarded as one (Van Vollenhoven, 2016:4-5). The question over whether archaeology is history or not has been concluded during the last quarter of the twentieth century. Heritage has also gradually become a part 
of both these disciplines. Just like History, both Archaeology and Heritage are historical disciplines and are aimed at studying the past, specifically the past as created by humans. Although this article does not aim to discuss the relationship between these three subjects in detail, attention is given to this relationship because heritage management, which stems directly from archaeology, forms a vital part of not only the collective historical knowledge we possess today, but also is imbedded in the national curriculum in South Africa (RSA, 2011:5, 34-35).

Du Bruyn (1983:30,38) states that archaeology is history, or at least should be regarded as such and goes further by declaring that in South Africa it is even more so as both disciplines aim at reconstructing and explaining the South African past. Dymond (1974:76-85) agrees when he states that both disciplines try to reconstruct the story of human life as fully and accurately as possible. It is mainly due to the incomplete evidence of both these subjects that they should be used complimentary to each other.

It is therefore clear that archaeology has long been accepted as being history. The best example of this is that general history publications since the 1980s usually start with a chapter on the prehistory of South Africa (e.g. Cameron $\&$ Spies, 1986; Pretorius, 2012) which relies on archaeological enquiry. Many other examples show that history and archaeology are intertwined to such an extent that they can no longer be regarded as being separate.

The discipline called "Heritage" also forms an integral part of the study of Archaeology and History. The scientific approach to heritage evolved in the USA during the 1970s where it originated as a sub-discipline of archaeology (Coetzee, 1991:3). It spread throughout the world becoming one of the many aspects archaeologists deal with (Renfrew \& Bahn, 1991:471-473). Since 1989 its inclusion has been common practice in South Africa (Deacon, 1996:841) and soon other historical disciplines, such as History, also added heritage to its study field (Coetzee, 1994:26). Heritage management was institutionalised with the promulgation of the National Heritage Resources Act (Act 25 of 1999). In this act History and Archaeology are both mentioned as key aspects in dealing with heritage.

The National Curriculum Statement for History includes the concept of heritage. Not only is it mentioned with History in the aims of the curriculum, but a heritage investigation forms part of the assessment programme of Grade 10 learners (RSA, 2011:5, 34-35). The three historical disciplines of History, Archaeology and Heritage, therefore, are unmistakably linked and it 
sometimes is extremely difficult to draw the line between these.

The East Fort Archaeological Project combines these three disciplines. In the project historical information from primary and secondary sources, for example documents and photographs, are combined with archaeological information gained through excavations and analyses of artefacts. The fort was built during the Anglo-Boer War (South African War), which is also a theme in the History curriculum (RSA, 2011:18) and as such is regarded as part of the heritage of South Africa.

In South Africa public participation seldom extends to physical involvement in the production of historical knowledge. Perhaps even more so, it is almost unthinkable to engage with school learners in doing research. In this article the East Fort Archaeological Project is presented as an example of how a participatory project can be mutually beneficial to the distinct archaeological discipline and secondary education spheres for learners.

\section{Public Archaeology}

Public Archaeology is the passing along of information discovered through the academic process to people outside of the profession. This is done through museum exhibits, the use of popular and social media and/or opening excavations to the public. This is done in order to promote stewardship of cultural resources and to make Archaeology, History and Heritage relevant to society (McDavid, 2002:2). In South Africa, this process is generally defined as civic involvement during the various public phases of Cultural Resources Management, in which communities are consulted on the heritage and significance of the archaeological and historical site in question. The National Heritage Resources Act (Act 25 of 1999) states in article 38 that communities affected by certain development processes that may impact on their heritage, should be consulted. These engagements sometimes broaden into community education and outreach endeavours. It, however, seldom extends towards public participation in the archaeological activities and/or the production of knowledge.

Although interaction between professionals and the public is desired, physical participation by the public in archaeological activities is often ignored and remains the proverbial "elephant in the room" within South Africa. Mick Aston reminds us that "members of the public do not have the expertise to become involved in brain surgery. In a similar fashion, there are aspects of archaeology which are too complicated for involvement without extensive expertise". However, he continues that "just as the public are capable of applying plasters and are involved in basic 
first aid, they can also be involved in some of the less complicated practical aspects of archaeology" (Aston 2012:447). Time Team producer, Jeremy Cross, aptly states: "professionalism does not mean - should not mean - that all archaeology can only be done by professionals" (Kennedy, 2003).

The existing dialogue between archaeologists and the public focuses on the narrative told by the archaeologist to the public. It has been argued that a power relationship exists in which archaeologists are producers of knowledge and the public are consumers of that same knowledge (Bartoy, 2012:557), and where innovations and ideas are seen as originating solely from the academics (Little, 2005:284). On the other hand Levine, Britt and Delle (2006: 399) explain that historic sites, like East Fort, should serve as a window into the past. They further state that the artefacts recovered should assists in narrating the story of that past to the public. This narration is the beginning of the dialogue that should exist between the archaeologists and the public. It is this dialogue that shapes a community and builds its awareness of heritage. This is the essence of public archaeology.

The existence of amateur bodies, such as the South African Archaeological Society, highlights public interest. Unfortunately, the public are rarely seen as possible contributors in the production of archaeological knowledge, despite some members being well-read and educated. Although it is understandable that these individuals cannot be given free rein to act as professionals, archaeologists must provide them with the necessary guidance to empower them to create academically sound narratives. If channelled correctly, the public's contribution to knowledge production will be of greater significance if they possess insight into archaeological research and are also allowed access to the existing knowledge base (Franklin \& Moe, 2012:570). Professional archaeologists should therefore foster the public's understanding of essential archaeological concepts, theory and practice with the long-term goal of creating an "archaeologically literate citizenry" (Franklin \& Moe, 2012:570). Academics, and in this case archaeologists, must therefore aim for Participatory Action Research, in which members of the public actively engage in research alongside academics, within an environment that inspires joint decisionmaking in terms of research aims and objectives (Baugher, 2007:188).

\section{Problem statement}

The authors are, apart from their academic specialities, all involved with public archaeological enterprises. During the course of this public work they 
were all confronted with the public's frustration at the lack of opportunity to participate in what the latter termed "real" archaeology. Members of the public are often knowledgeable and enthusiastic, yet they cannot find any opportunity to live out their passion or apply their knowledge.

The same comments were heard from high school learners and their parents as well as prospective tertiary students considering archaeology as a career. The latter group may suffer the most under this lack of civic involvement, as informative practical experiences, that may guide career choices, are almost wholly absent from the public sphere.

As a result the authors decided to join forces and create the East Fort Public Participation Initiative. Archaetnos ${ }^{1}$ acts as Principle Investigator, permit holder and main researcher and contributes many years of public participation experience through the Steinaecker's Horse Research Project. ${ }^{2}$ Heritagewor $X^{3}$ runs the educational and training side as well as logistics of the project.

The problem being addressed is whether public participation and educational exercises may play an academically valuable role in the production of archaeological knowledge. The article discusses the East Fort Archaeological Project and aims to provide an overview of the project from 2013 to the present and to look at the different aspects thereof, consisting of an orientation course, educational excursion and practical archaeological field work.

\section{East Fort Public Participation Initiative}

The East Fort Archaeological Project is regarded within the sphere of Public Archaeology (Public Engagement Archaeology). It encourages the active participation of the public in the archaeological excavation and the documentation of an archaeological site. This means that apart from the professional archaeologists who oversee the excavations, the excavators are members of the public. The excavations are advertised for anyone between the ages of 16 and 160. This lower age limit is deliberately set as the project leaders feel that younger learners might not be able to cope with the physical demands of the excavation. When enquiries for the participation of younger ages are received, it is insisted that one of the parents accompany the learner.

1 Archaetnos is a private company providing a service in cultural heritage management.

2 The Steinaecker's Horse Research Project is a private initiative and has been running for 20 years. Archaeological research is conducted on Anglo-Boer War sites in the Kruger National Park for two weeks each year. The project is based on the contribution of volunteers to do the physical excavations on site, while the professional archaeologist and historian does background research and compiles the research reports.

3 HeritageworX endeavours to fill the gaps and broaden the general understanding of those interested in the fields of heritage and archaeology with lectures, sandwich courses and practical experience that brings knowledge to life. 
The unrealistic upper age limit is in direct response to members of the public that express interest and then stating that they believe themselves to be too old to participate. It is explicitly stated that no prior knowledge is required and the only condition is interest and a degree of fitness needed for the physically taxing activities. All first-time participants are required to attend a two-day intensive "Introduction to Archaeology" course.

The research is done in line with ethical guidelines set out by the South African Heritage Resources Agency and the National Heritage Act (Act 25 of 1999). An excavation permit is obtained from the first mentioned and the permit conditions are adhered to. This includes, but is not limited to, standard protocols when dealing with such sites, for instance the full documentation and mapping thereof, careful packaging of excavated artefacts and expert analyses thereof.

\section{Theoretical framework}

The archaeological research of the East Fort site is done within the framework of the Heritage Resources Management Paradigm as developed by Van Vollenhoven (2000:553-555). This is an extension of the Contextual Paradigm, but with the emphasis on making heritage accessible to the community. The Contextual Paradigm is one of many post-processual theories in archaeology and is the only scientific framework directly linked to the concept of heritage management (Meyer, 1995:1-15; Van Vollenhoven, 1998:21-24). Furthermore, it is the only paradigm mentioned as having the possibility to be utilised in the public sphere, for instance providing knowledge to assist with land claims and tourism development (Hodder, 1995:168, 182).

Post-processual archaeological theory became popular in academic archaeology during the late 1970s and early 1980s. It proposes that there is no single paradigm of interpreting archaeological sites. Although different paradigms have different approaches, they all place emphasis on archaeological interpretations, the importance of archaeological context, the importance of a personal agent (the archaeologist) and the fact that interpretation of the past may possess political resonance in the present (Richardson \& AlmansSánches, 2015:196). However, it seems to be only the Contextual Paradigm that makes a direct link between education and archaeological theory (Van Vollenhoven, 2000:105-118).

The Heritage Resources Management Paradigm strives to link a historical site to a current community and therefore provides a wider applicability which 
is not only aimed at the production of knowledge, but also on the meaning the site could have for society. In this way it contributes to and potentially could assist any community with the preservation of local heritage. Such a community may only be a small section of the larger community (Van Vollenhoven, 2016:22). In this case the East Fort Archaeological Project not only contributes to the preservation of the heritage of the residents of the area, but to everyone who has an interest in the Anglo-Boer War, archaeology, heritage and education. As a project with an educational aim, it falls within the Educational Approach to Public Archaeology, one of four approaches constituted by Matsula, the others being Public Relations, Pluralist and Critical Approach (Matsula, 2016:3).

In summary the Heritage Management Paradigm views that:

- The cultural context of a historical or archaeological site creates a direct link with a section of the current society. This society may be direct descendants of those who created the site, anyone who regard the site as being important or anyone with a specific interest in the site.

- Communities have a need for their heritage to be researched, preserved and managed which is only possible within the thorough description and allinclusive evaluation, interpretation and explanation which this paradigm allows.

- Historical and archaeological sites can be optimally utilised and marketed for educational purposes when the research and management thereof is based on sound scientific principles.

The approach for the East Fort Archaeological Project therefore is a participatory methodological one where the public are contributing to the production of knowledge. At the same time the experts (archaeologists, historians etc.) assist the community in the preservation of the site and participation in an educational endeavour. The latter may be useful to assist History teachers in making History come alive and tangible.

\section{Course content}

\section{Introduction to Archaeology and participant orientation}

Over the four years that the project has been running, the participants have included two primary school learners and ten high school learners, as well as 18 adult enthusiasts older than 18 years. These people were enrolled or prospective Archaeology students, interested members of the public and/or 
members of the South African Society for Amateur Archaeologists. During a two-day orientation course, participants received course manuals and CDs containing recommended reading, tutorial videos and presentations. Participants were encouraged to participate actively in the orientation course by asking questions and contributing to the discussions through personal insights and experiences. The course serves to fulfil the following purposes:

- The introduction of participants to archaeological and historical sites;

- The creation of greater awareness of heritage and conservation;

- The facilitation of active communication and Participatory Action Research.

The course introduces participants to concepts not generally thought of by the general public, such as how sites are located, working in and with the law, artefact types and their analyses, the vital necessity of site documentation etc. The course follows a $60 \%$ theory and a $40 \%$ practical layout. Most of the lectures are followed by practical sessions to enhance the theory and also demonstrate how it is applied. HeritageworX is responsible for writing and presenting the Introduction to Archaeology course. As they firmly believe and reinforce the mantra "the only stupid question is the one not asked", effort is made to ensure that all the participants understand the course material. The course material is written and presented in an easily digestible format while still remaining academically sound. The parents of the two primary school learners were specifically asked to make sure their children understand the lectures. The same effort is afforded to all participants regardless of age or knowledge level and questions are encouraged throughout every lecture. This method has proved very valuable in that, during the fieldwork, participants were heard linking the practical to the theoretical aspects, proving that the course material was understood and absorbed.

One of the main aims of archaeology is to reconstruct past ways of life (Renfrew \& Bahn, 1991:11-14). The theoretical concept of analysing artefacts is explained during the practical garbology ${ }^{4}$ exercise. During this exercise participants are grouped and each group receives a full garbage bag. From this they have to create narratives for each household/individual, reconstructing their daily habits based purely on the physical and documentary evidence revealed by ordinary household objects. Feedback is given by the group with explanations on why the conclusions were reached. A variety of theories are constructed surrounding the contents of each garbage bag's profile. Wild conspiracy theories regarding the possible links between the owners of garbage

4 Literally referring to 'garbage', in this case household garbage. 
bag $\mathrm{A}$ and $\mathrm{B}$ arise to much fun and laughter. The desired result is achieved through questioning and asking for explanations to the answers given. Lateral thinking is encouraged and this in turn fuels the synthesis of information.

The second day of the course is mainly devoted to the practical aspects of archaeological fieldwork, i.e. setting up an excavation grid, completing context sheets and making plan view drawings.

\section{Image 1: Theoretical training}

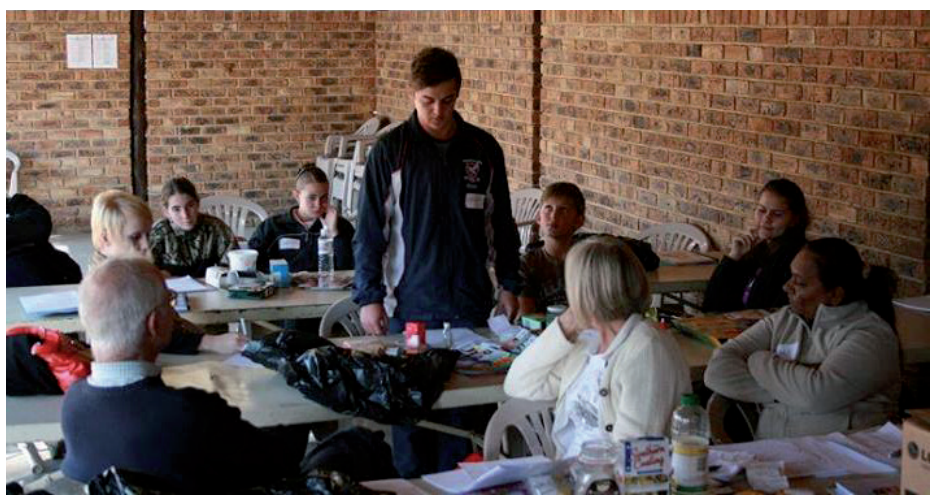

Source: AM Harcombe, 2013.

Image 2: Completing context sheets and making plan view drawings

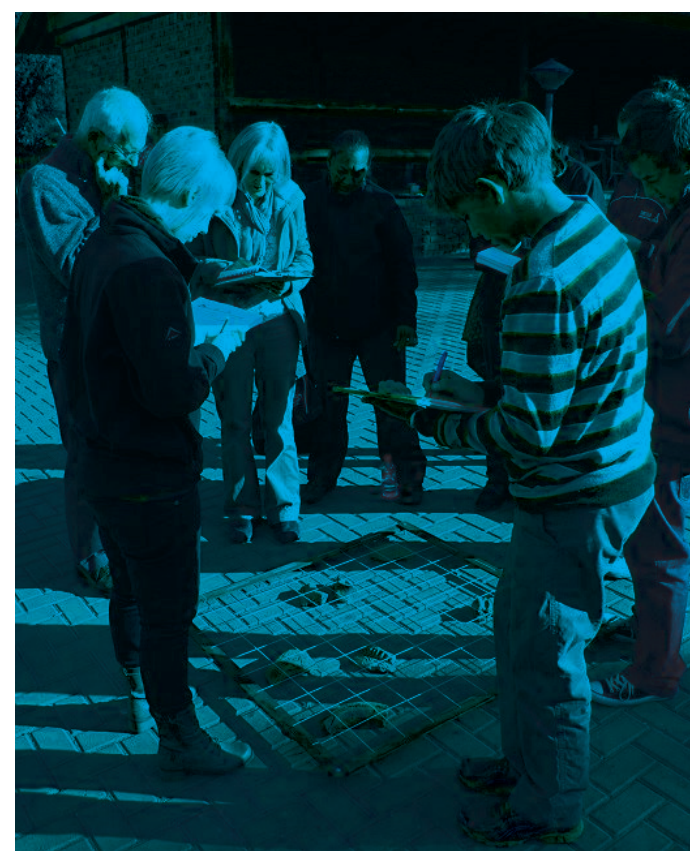

Source: AM Harcombe, 2013. 


\section{Excursion to Fort Daspoortrand and the West Fort community (2013)}

In 2013 the participants were taken on a tour of the ruins of Fort Daspoortrand (West Fort). Although this fort was larger and structurally more impressive than East Fort, its crumbling state highlighted the natural degradation of structures in the archaeological record.

All the participants, regardless of age, asked insightful questions and offered valuable insights on the topics of history, architecture, warfare and engineering. The high school learners, of whom one may sometimes expect simple or even irrelevant questions, came up with surprisingly logical ideas and sensible arguments. The authors feel that the questions posed by the participants had a wide scope and showed "out of the box" thinking. If the group were restricted to trained archaeologists, the questions would have been more focused and in line with their expertise and training. The value of fresh, unbiased input from individuals outside the professional realm of archaeology made it clear that members of the public, regardless of their age or background, could produce viable interpretations of archaeological evidence.

Issues surrounding the conservation of historical buildings were highlighted by a site visit to the West Fort community, where a mixed community now occupies the buildings and grounds of the old Pretoria Leper Hospital. Questions relating to the continued civic use of historical buildings after their official abandonment were asked and concerns about the impending destruction of the neighbourhood were raised. This visit provided an excellent opportunity to educate the general public to regard history and heritage as a whole in a responsible way, a concept that was raised as far back as 1995 (Van Vollenhoven, 1995).

Unfortunately due to the socio-economic deterioration of the area surrounding Fort Daspoortrand, security concerns have made that it is no longer possible to take the participants on this tour.

\section{The East Fort excavations as an example of practical archaeological field work}

The excavations are normally scheduled for the week after the introduction course, during the July school holidays. The theoretical information learned is fresh in the minds of the participants. Each individual excavation is led by an experienced post-graduate student, called a Trench commander, many of whom are also members of the Association of Southern African Professional Archaeologists. A team will consist out of high school learners, university 
students and members of the public. The mix is intentional as the participants have to learn to work together in a team and assist each other.

Trench commanders are carefully chosen for their skills in working with the public. They need to be able to manage younger and older participants. They are required to encourage participants actively to ask questions and engage in conversations. This is achieved by reinforcing the concept introduced during the weekend course that there are no stupid questions. The Trench commanders treat all questions and suggestions seriously and encourage group discussions. These discussions can be brought up at the communal lunches where everyone's opinion and participation is asked for. Each day starts with the Site Director giving an overview of what is expected for the day and ends with a summary of what was achieved, as well as highlighting noteworthy findings.

The first day of excavations always kicks off with a great level of enthusiasm. Although uncertainty over some aspects of the excavation is clearly visible, expressions soon transforms into gestures of understanding and confidence. The day starts with the Site Director leading a site tour. During this tour the archival photographs and documents of the fort are used to show the layout of the fort. It is explained how these documents assist archaeologists to decide where to excavate and how this context could help in interpreting the artefacts found and in writing up the history of the site.

By day two, everyone is accustomed to the routine and is conscious of the work ahead. In spite of fatigue setting in, participants are well-aware of the time constraints and do their best to achieve the daily targets. Trench commanders attempt to utilise the strengths and weaknesses of their individual team members and focus on creating cohesive and productive units. Physically strong individuals are commandeered to assist groups where muscle is needed, while those less physically able are used to take charge of sorting and documentation. Where the soil is exceptionally hard or compacted with small stones (due to the collapsed Rice Pattern walling) ${ }^{5}$ the experienced excavators are brought in to assist. In more than one instance, the subject knowledge and logical reasoning skills of older participants greatly outweigh their contributions in terms of the physical excavation.

5 The Rice pattern refers to a type of blockhouse, invented by Maj. SR Rice of the Royal Artillery. It consisted of different shapes made out of galvanized corrugated iron. These usually had a wooden frame, with a double corrugated iron wall attached thereto and with small stones in between. By January 1901 the large scale erection of blockhouses was at the order of the day. At first these were octagonal in shape, but from March 1901 circular shaped ones were also made National Archives of South Africa (NASA, A1619:278-279). 
Participants are involved in the administration of their excavation and each participant is afforded a chance to write their excavation's field notes for the day. Participants are also in charge of the labelling and packing of the artefacts collected and, if required, drawing of in situ artefacts or excavation trench profiles drawings. On the last day of the excavation, individual trenches are closed down and sandbagged waiting reopening the following year. The week's activities are wrapped up and each participant is awarded a Certificate of Participation.

\section{Image 3: The site director teaching site drawing}

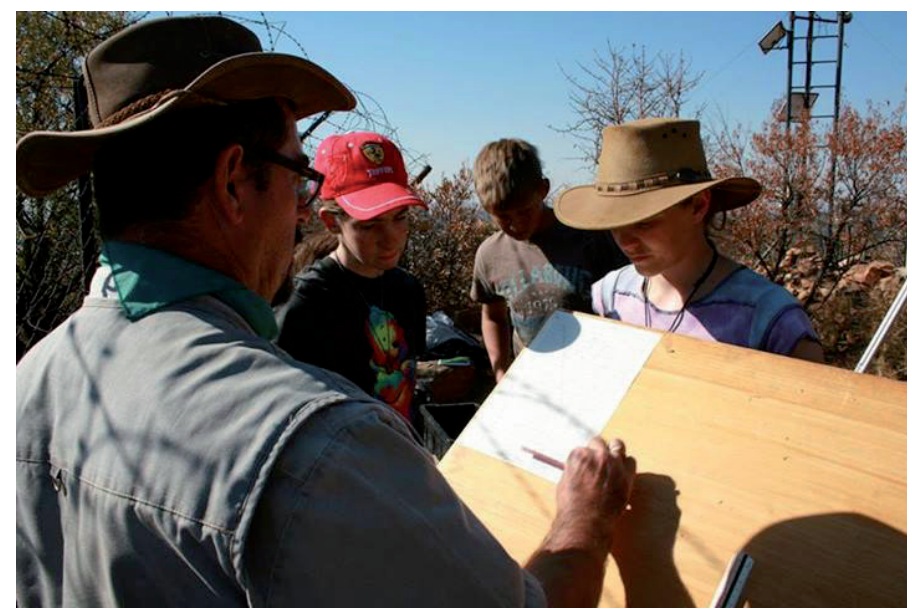

Source: AM Harcombe, 2013.

Image 4: One of the excavation teams hard at work

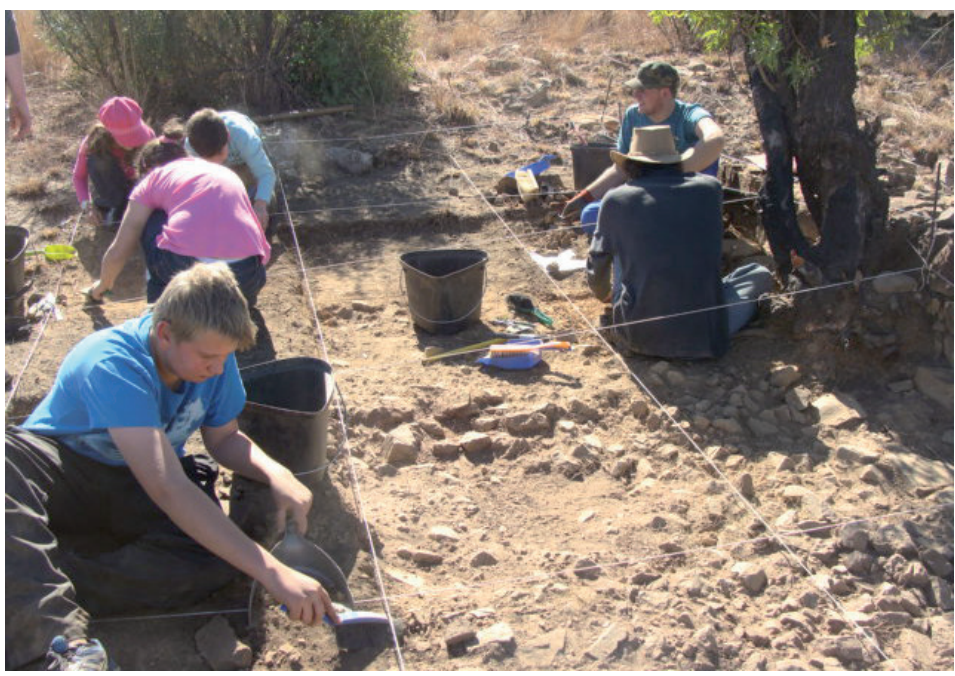

Source: AM Harcombe, 2013. 


\section{Discussion}

\section{Interpreting Feedback}

It is important to acknowledge Bartoy's (2012:558) recommendation that course programmes should be evaluated in order to assess whether or not the educational objectives have been reached. This is especially true since having a good time does not necessarily result in actual learning. Thus, each team member participating at East Fort is requested to complete a feedback form and the responses are overwhelmingly positive. The critique is constructive and helps in identifying and addressing problem areas in either the course or in the fieldwork. The participant feedback is used in future marketing and in publications and presentations, popular and academic, about the project. Their consent is obtained in a direct question on the feedback form.

During the early Introduction to Archaeology courses it was suggested by the Trench commanders with prior experience as educators, that the content of the orientation course could be restructured to suit the requirements of younger participants. Thus by including more examples from international archaeology that act as drawing cards for the discipline through channels like National Geographic, these examples will be complimented, where possible, with examples from local archaeology. After all, the public expect us to reveal an exciting world that teaches them about our past, not some grand epistemology (Franklin \& Moe, 2012:566). It is always encouraging to see that the participants, especially the school learners, know about these international examples (e.g. Stonehenge and the Egyptian pyramids) and even some of the more well-known South African ones (e.g. Mapungubwe), although the local heritage is not at all as well known as the international ones.

\section{Expectations of field work}

It was envisaged that the first excavation season (2013) would take the form of a structural dig in which a comparison would be drawn between the 1979 site map, compiled by Mervin Emms and the remaining physical features. The material record is not rich in terms of artefacts but a number of unique items did emerge which ignited great enthusiasm. The objects were of an everyday nature, and far from spectacular, but it was clear that the participants held more realistic expectations of the artefact record. It became apparent that no one was disappointed by the lack of jade masks, golden rhinos or crystal skulls. Indeed bullet casings, glass shards with maker's marks and partial smoking pipe stems proved just as exciting. These outlooks indicated that, despite 
the original attention fuelled by pop-culture archaeology and romanticised documentaries, members of the public possess a more realistic expectation of archaeology than previously thought.

\section{Career guidance}

During the introduction course the lecture on the fields of specialisation within the discipline most everyone finds an eye-opener. Sending prospective Archaeology students into the field can have dual consequences. They can either recognise their expectations of the discipline were misguided and make the informed decision to follow another career path, or confirm that their interests were based on certain truths and that the added experience and newly gained information, solidified their decision to pursue archaeology as a career. Whatever the case, both scenarios result from the provision of career guidance and practical experiences gained nowhere else but through Public Archaeology. The perception that all artefact analysis is done by the archaeologist him/herself is laid to rest. Archaeological fieldwork is generally held by the public as the be all and end all of archaeology. In the media very little attention is paid to the analyses of the material and when findings are presented it is normally the lead archaeologist who is interviewed. This creates the perception that he/she alone is responsible for every aspect of the physical excavation to the writing of the final report.

The impression is thus created that if you are not fond of working outside, you cannot be an archaeologist. In conversations with students the knowledge gained in this lecture not only showed them that they do not have to be a field archaeologist to make a valuable contribution in the discipline. It also exposed them to understudied areas in the discipline. In conversations with the learners they mentioned that they thought they could not combine their particular interest, for example art or mechanics, with their interest in archaeology. They thought that by studying their main field of interest, they would have to give up their interest in archaeology.

The other side of the coin is that many believe fieldwork is exactly as it is portrayed by the media or in the movies such as the Indiana Jones films with spectacular finds and dangers lurking around every corner. Sending prospective Archaeology students into the field before they start studying or early in their university education can help them to recognise that their expectations of the discipline were misguided and to make the informed decision to follow another career path. The consensus among all is that, 
within the overly romanticised world of pop-culture or inadvertently created perceptions in archaeological documentaries, a true archaeological experience is exactly what the public needs.

\section{Findings}

Each year the project goes from strength to strength and the previous participants encourage new participants because of their personal experiences and knowledge gained. Each year also brings new ways of interacting and new groups to interact with. It can be stated unequivocally that the East Fort Archaeological Project is a success because the basic premise remains firmly imbedded in principles of academia and archaeological ethics while creating an enjoyable experience for all who participate. The project further proves that the public, regardless of age or skills level, can participate in and assist with the production of archaeological knowledge.

Adhering to the fundamental principles of archaeology means proper orientation, pre-fieldwork education, on-site training, as well as consistent supervision, guidance and the maintenance of site ethics. There is no reason to dumb down information or compromise on academic standards just because you are dealing with learners and non-professionals. From the authors and other archaeologists' (Trench commanders) experience there is no reason why the public (in this case school learners, students and other volunteers) should not be involved in real archaeological projects.

Furthermore, the project can be seen as a test case study for History teachers and could add value to the heritage component in the national curriculum. As with other aspects which are annually evaluated and improved, the educational component needs improvement, inter alia by not only evaluating the experience of learners, but providing them with a specific assignment to be completed and evaluated. The programme can for instance be run in concert with schools, therefore allowing an entire History class to attend during the semester (currently the programme is hosted during the school holidays). As such it will have a more direct bearing on the national curriculum.

\section{Conclusion}

As the East Fort project evolves, some transformation and revision has already taken place. The feedback received from the participants as well as the questions and comments during the course and fieldwork is reviewed 
and applied after every excavation. The fundamentals by which the successes can be measured and carried forward have been established. The central achievement is that the project managed to move away from the popularist view that archaeology is a "fun digging activity". It provides a more realistic vision of archaeology as "a way to study and learn about the past" (Lewis, 2007:305). Participants derive enjoyment and learning from the experience

From the feedback it is clear that part of the enjoyment originated from knowing that it is a real excavation. Participants gave a positive response in knowing that their hard work and sweat was generating actual knowledge and making a contribution to the archaeological and historical record of South Africa. This is the start of fostering the much needed dialogue between the archaeologists and the public.

Exposing and educating specifically the learners to real tangible history and the archaeological process makes them conscious of heritage and history, the importance of it being studied and above all, the importance of it to be conserved. The active participation in an on-going research project makes it relevant to learners and brings the heritage to life. It shows that history is exciting and needs to be taken out of books in order for learners to be captured by it. If possible, archaeologists should be involved in the History learning program for schools. This can be done by learners participating in projects like the East Fort Archaeological Project, but at the very least archaeologists could visit schools to give guidance with regards to the heritage section of the History curriculum.

The project therefore serves as proof that the public can contribute to the production of our knowledge of the past. Apart from the scientific site reports created, the research has already been published in peer reviewed journals and presented at conferences. Without the participation of the volunteers and learners, this would not have been possible.

Although the East Fort Archaeological Project deals with only a small part of South African history, illustrating how it fits into the whole creates a willingness to learn more. The project engages with the learners in a nontraditional educational environment and the discussion of Archaeology, History and Heritage is an alternative way of dealing with these subjects. In this way the project, or similar ones, may also benefit History teachers in realising an active way of creating awareness about Archaeology, History and Heritage. At the very least it would assist in the heritage investigation that Grade 10 learners are assessed on. The excitement of finding artefacts and 
being taught about the meaning of each makes history alive. It affords the opportunity to be part of the creation of historical knowledge in a way the classroom cannot.

\section{References}

Aston, M 2012. Publicizing Archaeology in Britain in the late twentieth century: A personal view. In: R Skeates, J Carman \& C McDavid (eds.). The Oxford handbook of Public Archaeology. New York: Oxford University Press.

Bartoy, KM 2012. Teaching through, rather than about. Education in the context of Public Archaeology. In: R Skeates, J Carman \& C McDavid (eds.). The Oxford handbook of Public Archaeology. New York: Oxford University Press.

Baugher, S 2007. Service-Learning: Partnering with the public as a component of college Archaeology courses. In: JH Jameson \& S Baugher, S (eds.). Past meets present. Archaeologists partnering with museum curators, teachers and community groups. New York: Springer.

Cameron, T \& Spies, SB (eds.) 1986. Nuwe Geskiedenis van Suid-Afrika in woord en beeld. Cape Town: Human \& Rousseau.

Coetzee, I 1991. Cultural resources management defined. Muniviro 8(1):3.

Coetzee, I 1994. Cultural resources - a tour through our world in one country. In: W Loots. Kultuurhulpbronne \& Streekstoerisme. Pretoria: National Cultural History Museum.

Deacon, J 1996. Cultural resources management in South Africa: Legislation and practice. In: G Pwiti \& R Soper (eds.). Aspects of African Archaeology. Harare: University of Zimbabwe Publications.

Du Bruyn, J 1983. Geskiedenis en Argeologie. Historia 28(1):30-38.

Dymond, DP 1974. Archaeology and History: A plea for reconciliation. London: Thames and Hudson Ltd.

Franklin, ME \& Moe, JM 2012. A vision for Archaeological literacy. In: R Skeates, J Carman \& C McDavid (eds.). The Oxford handbook of Public Archaeology. New York: Oxford University Press.

Hodder, I 1995 Reading the past. Current approaches to interpretation in archaeology. $2^{\text {nd }}$ edition. Cambridge: Cambridge University Press. 
Kennedy, M 2003. Time team digs up row over DIY excavation. The Guardian, Saturday 21 June. Available at http://www.theguardian.com/media/2003/jun/21/schools. artsandhumanities. Accessed on 13 September 2016.

Levine, MA, Britt, KM \& Delle, JA 2006. Heritage tourism and community outreach: Public Archaeology at the Thaddeus Stevens and Lydia Hamilton Smith Site in Lancaster, Pennsylvania, USA. International Journal of Heritage Studies, 11(5):399-414.

Lewis, A-EH 2007. Transportation collections: On the road to public education. In: JH Jameson, \& S Baugher (eds.). 2007. Past meets present. Archaeologists partnering with museum curators, teachers and community groups. New York: Springer.

Little, BJ 2005. Envisioning engaged and useful archaeologies. In: M Rockman, \& J Flatman, (eds.). Archaeology in society: Its relevance in the modern world. New York: Springer.

McDavid, C 2002. From real space to cyberspace: The internet and Public Archaeological Practice. Unpublished PhD thesis. Cambridge: University of Cambridge.

Meyer, A 1995. Argeologie en kultuurhulpbronbestuur: 'n Voorgestelde paradigma vir kultuurhulpbronbestuur. In: J van den Bos \& M Moolman, (eds.). Metodologie in navorsing. Sunnyside: SASCH Transvaal Branch.

National Archives of South Africa (NASA), Pretoria, Transvaal Archives (TAD), A1619: E.H. Bethell, The blockhouse system in the South African War, Professional papers of the Royal Engineers:278-279.

Pretorius, F (ed.) 2012. Geskiedenis van Suid-Afrika. Van voortye tot vandag. Cape Town: Tafelberg.

Renfrew, C \& Bahn, P 1991. Archaeology. Theories, methods and practice. USA: Thames and Hudson Ltd.

Republic of South Africa. 1999. National Heritage Resources Act (No 25 of 1999). Pretoria: The Government Printer.

Republic of South Africa. 2011. National Curriculum Statement (NCS), History, Grades 1012. Pretoria: Department of Basic Education.

Van Vollenhoven, AC 1995. Die bydrae van argeologie tot kultuurhulpbronbestuur (KHB). In: J van den Bos \& M Moolman, (eds.). Metodologie in navorsing. Sunnyside: SASCH Transvaal Branch.

Van Vollenhoven, AC 1998. Kultuurhulpbronbestuur (KHB) binne die funksionele konteks van museums in SuidAfrika. Ongepubliseerde MA-verhandeling. Stellenbosch: Universiteit van Stellenbosch. 
Van Vollenhoven, AC 2000. 'n Voorgestelde paradigma vir navorsing op histories-argeologiese erfenishulpbronterreine in Suid-Afrika aan die hand van gevallestudies in Noordelike Gauteng. Ongepubliseerde DPhil-verhandeling. Pretoria: Universiteit van Pretoria.

Van Vollenhoven, AC 2016. Erfenisriglyne. 'n Praktiese gids vir alledaagse gebruik. Pretoria: V\&R Printers. 